Web Jurnal:

http://ejournal.kemenperin.go.id/jli

\title{
Pendugaan umur simpan sediaan bawang tunggal hitam dengan metode accelerated shelf-life testing (ASLT)
}

\section{Shelf-life prediction of solo black garlic products using accelerated sheft-life testing (ASLT) method}

\author{
Gunawan Priadi*1, Fitri Setiyoningrum ${ }^{1}$, Fifi Afiati', Hisaqia Amieni ${ }^{2}$ dan Muhamad Arpah ${ }^{2}$ \\ 1 Pusat Penelitian Bioteknologi-Lembaga Ilmu Pengetahuan Indonesia \\ Jalan Raya Bogor KM 46, Cibinong Bogor, Indonesia \\ 2 Departemen Ilmu dan Teknologi Pangan Fakultas Teknologi Pertanian-IPB \\ Kampus IPB Darmaga, Bogor, Indonesia \\ * gunawan.priadi@ymail.com; guna006@lipi.go.id
}

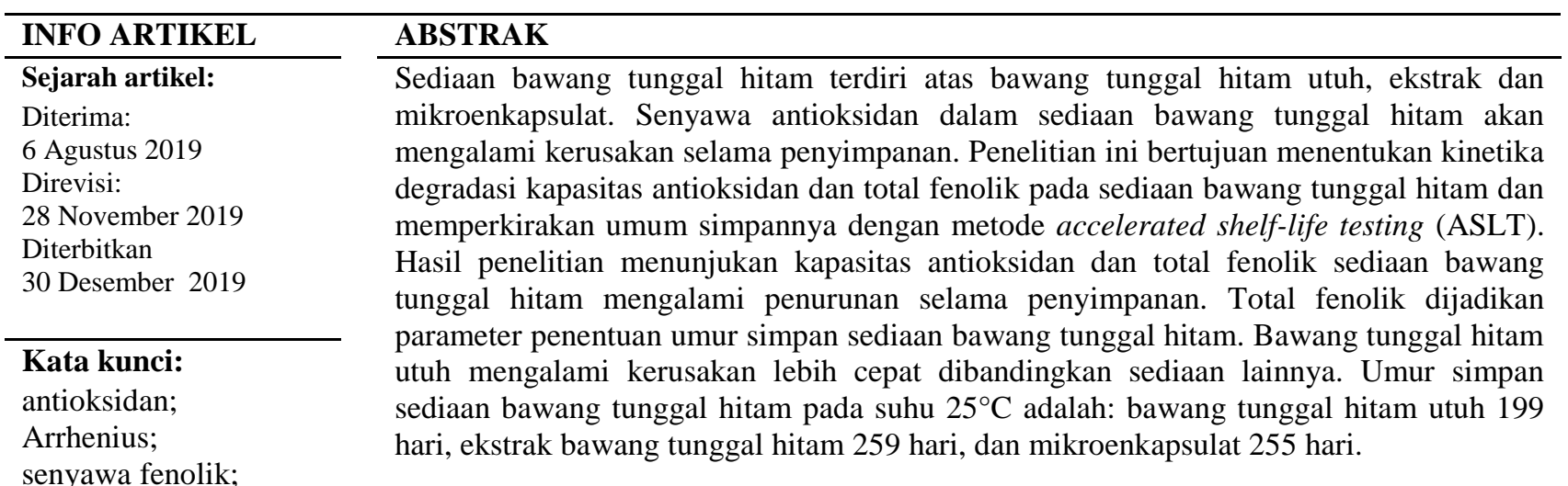

konstanta reaksi

\section{Keywords:}

antioxidant;

Arrhenius;

phenolic compounds;

constanta of reaction

\begin{abstract}
Solo black garlic products consisted of whole solo black garlic, extract, and microencapsulated. Antioxidant compounds in the black garlic products will be damaged during storage. The study was aimed to determine the kinetics degradation of antioxidant capacity and total phenolic of black garlic products and to estimate their shelf life using accelerated shelf life testing (ASLT) method. The result showed that antioxidants and total phenolic of products decreased during storage. Total phenolic was used to predict the shelf life of products. The whole black garlic deterioration is faster than other products. The shelf life of whole black garlic, black garlic extract and microencapsulated black garlic extract at $25^{\circ} \mathrm{C}$ were 199 days, 259 days, and 255 days respectively.
\end{abstract}

C 2019 Penulis. Dipublikasikan oleh Baristand Industri Padang. Akses terbuka dibawah lisensi CC BY-NC-SA

\section{Pendahuluan}

Bawang hitam merupakan produk pengembangan bawang putih. Pembuatan bawang hitam dilakukan dengan cara memeram bawang putih pada suhu dan kelembaban tinggi selama waktu tertentu (Bae et al., 2014; Choi et al., 2014; Kimura et al., 2017; Ngan et al., 2017). Metode lainnya adalah dengan perlakukan enzim dan curing (Wang dan Sun, 2017). Keunggulan bawang hitam dibandingkan bawang putih diantaranya meningkatnya kandungan S-alil-sistein 5-6 kali (Bae et al., 2012), umur simpan lebih lama (Chu et al., 2007), kandungan senyawa fenolik lebih tinggi 5-8 kali (Kim et al., 2013), dan berkurangnya off flavor (Kimura et al.,
2017). Bawang tunggal hitam memiliki rasa yang lebih manis (Ngan et al., 2017) yang disebabkan oleh peningkatan kadar glukosa, fruktosa dan sukrosa (Zhang et al., 2016), dan tekstur lengket seperti jeli (Bae et al., 2014). Manfaat bawang tunggal hitam diantaranya menurunkan lemak tubuh dan hiperlipidemia (Kim et al., 2011), mempunyai efek antioksidan dan anti inflamasi (Jeong et al., 2016), menurunkan kadar lipid, trigleserida dan kolesterol darah (Ha et al., 2015) dan mempunyai nilai teurapetik untuk penderita leukemia (Park et al., 2014). Bawang hitam telah dikonsumsi oleh orang-orang di Korea Selatan, Thailand dan Jepang sebagai flavor dalam memasak dan dikonsumsi langsung. 
Sediaan bawang hitam terdapat dalam bentuk utuh, ekstrak dan mikroenkapsulat. Ekstrak merupakan sediaan pekat yang diperoleh dengan mengekstraksi zat aktif dari simplisa nabati atau hewani menggunakan pelarut yang sesuai, kemudian semua atau hampir semua pelarut diuapkan (Agoes, 2007). Sedangkan mikroenkapsulasi merupakan suatu teknologi penyalutan padatan, cairan, dan gas oleh kapsul dalam bentuk kecil yang dapat melepaskan senyawa di dalamnya pada kondisi spesifik (Susanti, 2008). Teknologi mikroenkapsulasi dapat memberikan perlindungan terhadap komponen pangan yang sensitif, menutupi rasa pahit dan sepat dari polifenol (Reis et al., 2017). Pada sediaan utuh, semua komponen bioaktif terikat pada jaringan alami pembawanya. Proses ekstraksi menyebabkan komponen bioaktif terlarut dalam pelarut yang digunakan. Sediaan ekstrak hanya mengandung komponen bioaktif yang kepolarannya sama dengan pelarut. Sedangkan proses mikroenkapsulasi mengikatkan komponen bioaktif tertentu (yang terlarut dalam ekstrak) dalam matrik pembawa untuk dapat mempertahankan dan atau memperbaiki sifat fungsionalnya.

Kandungan antioksidan bawang hitam dapat menurun selama penyimpanan. Oksigen, cahaya, uap air dan suhu tinggi menjadi faktor penyebab rusaknya senyawa antioksidan. Kerusakan ini akan memperpendek umur simpan produk. Umur simpan didefinisikan sebagai rentang waktu pada kondisi penyimpanan yang ditetapkan di mana makanan masih dapat diterima untuk dikonsumsi dalam hal keamanan, nutrisi, dan karakteristik sensorik (Jedermann et al., 2014). Untuk mengetahui umur simpan suatu produk pangan dilakukan dengan uji pendugaan umur simpan. Metode yang digunakan diantaranya dengan studi literatur, distribution turn over, distribution abuse test, consumer complaints dan accelerated shelf-life testing (ASLT) (Asiah et al., 2018; Hariyadi, 2004; Mulyono et al., 2018). Untuk mendapatkan uji pendugaan yang cepat dan murah, metode ASLT banyak digunakan oleh industri.

Metode ASLT merupakan metode pendugaan umur simpan yang menggunakan parameter kondisi lingkungan yang dapat mempercepat proses penurunan mutu. Prinsip metode ASLT adalah menghitung pengaruh lingkungan luar terhadap laju kerusakan produk melalui kinetika kimia (Herawati, 2008). Produk akan diletakkan pada kondisi lingkungan terkontrol dimana satu atau lebih faktor yang mempengaruhi laju kerusakan dinaikkan sehingga laju kerusakan akan terakselerasi dan menyebabkan produk mengalami kerusakan lebih cepat. Salah satu faktor yang dapat memepercepat laju kerusakan suatu produk pangan adalah suhu.

Model Arrhenius merupakan model akurat yang menggambarkan pengaruh suhu terhadap laju kerusakan suatu bahan atau produk pangan (Steele, 2000). Produk yang mengalami penurunan kualitas akibat efek deteriorasi kimiawi umumnya menggunakan model Arrhenius (Arpah, 2007) seperti oksidasi, reaksi mailard, dan denaturasi protein (Asiah et al., 2018). ASLT model Arrhenius umumnya menggunakan 3 suhu penyimpanan di atas suhu normal (suhu ruang) untuk memprediksi umur simpan pada suhu yang diinginkan. Persamaan Arrhenius dapat menggambarkan korelasi antara perubahan parameter kualitas produk terhadap suhu penyimpanan.

ASLT model Arrhenius dapat digunakan untuk memprediksi umur simpan berbagai produk diantaranya produk segar : bibit kedelai (Rahmi et al., 2016), alpukat (Muliadi, 2019); produk kering : kacang rendah kemak (Pranoto et al., 2012), dendeng ikan (Gitalasa et al., 2018); produk ekstrak : ekstrak bunga echinaceae (Solco, 2007); minuman : sari buah nenas, pepaya, dan cempedak (Arif, 2016), sirup buah tin (Mulyono et al., 2018); produk bubuk dan mikroenkapsulat : seasoning (Budijanto et al., 2010), bubuk bawang merah goreng (Setyadjit et al., 2017), dan mikroenkapsulat jahe (Parsetiorini, 2011). Kandungan senyawa kimia dalam bahan dapat digunakan sebagai titik kritis penentuan umur simpan seperti vitamin C (Arif, 2016; Puri et al., 2018), angka peroksida dan asam lemak bebas (Diniyah et al., 2015), nilai TBD (thio barbituric acid) (Kurniadi et al., 2017), dan kadar antioksidan dan total fenolik (Rahmawati, 2017).

Kandungan antioksidan dan total fenolik yang tinggi menjadi nilai fungsional bawang hitam. Nilai ini tidak akan maksimal jika produk telah mengalami kerusakan (degradasi/penurunan kualitas) saat disimpan. Tujuan penelitian ini adalah menentukan kinetika degradasi kapasitas antioksidan dan total fenolik pada sediaan bawang tunggal hitam dalam bentuk utuh, ekstrak, dan mikroenkapsulat untuk menduga umur simpannya dengan metode ASLT model Arrhenius. Bawang tunggal hitam adalah bawang putih tunggal yang telah mengalami proses fermentasi menjadi hitam. Informasi umur simpan produk bawang tunggal hitam akan memberikan manfaat dalam menentukan pilihan produk yang tepat sebagai bahan baku, bahan tambahan atau produk akhir untuk industri.

\section{Metode}

Penelitian ini dilaksanakan pada Januari-Mei 2019 di Pusat Penelitian Bioteknologi-LIPI, Cibinong Bogor Jawa Barat. Bahan-bahan yang digunakan adalah bawang putih tunggal dari Pasar Anyar Bogor, maltodextrin, kemasan metalized plastic, kemasan PET (polyethylene terephthalate), aquades steril, metanol, metanol 70\%, pereaksi Folin ciocalteu 10\%, larutan $\mathrm{Na}_{2} \mathrm{CO}_{3} 7 \%$, Tween 80, kertas saring, alluminium foil, DPPH (2,2-diphenyl-1-picryldydrazil) dan pelarut kimia lainnya yang berkualitas pro analyisis. Bawang putih tunggal adalah bawang putih yang hanya memiliki satu siung (siung tunggal). Peralatan yang digunakan diantarnya neraca analitik (Shimadzu, Filipina), blender (Cosmos, China), freeze dryer (Christ Alpha 2-4 Ldplus, Jerman), rotary evavorator (Heidolph, Jerman), kondensor refluks, inkubator (Raypa, Spanyol), inkubator (Indelab, Spanyol), refrigerator, homogenizer (Ultra Turrax IKA, Jerman), spektrofotometer UV-Vis (Shimadzu, Jepang), vorteks, dan sentrifus (Hitachi CR21G III, Jepang) dan alat-alat gelas lainnya. 


\subsection{Pembuatan bawang tunggal hitam utuh (modifikasi Choi et al., 2014)}

Bawang putih tunggal dibersihkan dari tanah dan kotoran lainnya dan dikemas dalam alluminiun foil kemudian dimasukkan dalam inkubator suhu $70^{\circ} \mathrm{C}$, kelembaban $60-80 \%$, dan diinkubasi selama 21 hari.

\subsection{Pembuatan ekstrak bawang tunggal hitam}

Bawang tunggal hitam dikupas kulitnya dan ditimbang. Kemudian dihaluskan dan ditambah aquades dengan perbandingan 1:5. Campuran dipanaskan (refluks) $80^{\circ} \mathrm{C}$, dan dipertahankan suhunya selama 2 jam. Hasil refluks disentrifugasi $9000 \mathrm{rpm}, 20$ menit dengan suhu $10^{\circ} \mathrm{C}$. Supernatan disaring dan diuapkan menggagunakan rotary evaporator sampai volume akhir menjadi seperlima (1/5) dari volume pelarut. Ekstrak bawang tungga hitam disimpan pada refrigerator sebelum digunakan.

\subsection{Mikroenkapsulasi ekstrak bawang tunggal hitam (modifikasi Iriani et al., 2014)}

Mikroenkapsulasi diawali dengan pembuatan larutan maltodextrin $33,33 \% \quad(\mathrm{~b} / \mathrm{v})$. Seratus g maltodextrin dilarutkan dalam $300 \mathrm{~mL}$ aquades dan dihomogenisasi pada $6000 \mathrm{rpm}, 5$ menit. Kemudian larutan maltodekstrin direhidrasi pada suhu $10-12^{\circ} \mathrm{C}, 18$ jam. Sebanyak $100 \mathrm{~g}$ ekstrak bawang tunggal hitam dilarutkan dalam larutan maltodektrin. Larutan dihomogenisasi $6000 \mathrm{rpm}, 5$ menit dan ditambahkan Tween-80 sedikit demi sedikit sebanyak $10 \mathrm{~g}$. Larutan diliofilisasi pada suhu $-60^{\circ} \mathrm{C}$ dan tekanan 0,011 mbar selama 24 jam.

\subsection{Persiapan sampel untuk analisis}

Bawang tunggal hitam dan mikroenkapsulat sebanyak 0,2 g ditambahkan $500 \mathrm{l}$ larutan metanol $70 \%$. Sampel dipanaskan pada suhu $70^{\circ} \mathrm{C}, 10$ menit kemudian sampel didinginkan dan disentrifugasi $7840 \mathrm{~g}$, 10 menit. Supernatan yang diperoleh dipisahkan untuk sampel analisis. Sedangkan untuk sampel ekstrak bawang tunggal hitam diperoleh dengan mengencerkan $0,4 \mathrm{~mL}$ ekstrak menjadi volume $2 \mathrm{ml}$.

\subsection{Analisis kapasitas antioksidan (Muanda et al., 2011)}

Dua ratus mikroliter sampel dan 800 1 larutan DPPH 0,2 mM dimasukan pada tube 1,5 mL, kemudian kocok perlahan. Inkubasi sampel selama 30 menit pada suhu ruang dan kondisi gelap. Sampel kemudian disentrifugasi dengan kecepatan 9000 rpm selama 10 menit. Absorbansi sampel diukur pada panjang gelombang $517 \mathrm{~nm}$. Blanko sampel dibuat dengan mengganti sampel dengan methanol. Standar yang digunakan yaitu larutan asam askorbat. Kapasitas antioksidan dinyatakan dalam Ascorbic acid Equivalent Antioxidant Capacity (AEAC).

\subsection{Analysis total fenolik (modifikasi Choi et al., 2014)}

Sampel sebanyak $50 \quad 1$, aquades steril $800 \quad 1$ dimasukan pada mikrotube $1,5 \mathrm{~mL}$ yang telah dilapisi dengan aluminium foil. Sebanyak 501 pereaksi Folin Ciocalteu $10 \%$, dan $100 \quad 1$ larutan $\mathrm{Na}_{2} \mathrm{CO}_{3} \quad 7 \%$ ditambahkan pada tabung ependorf kemudian kocok perlahan. Inkubasi sampel selama 30 menit pada suhu ruang dan kondisi gelap. Absorbansi diukur pada panjang gelombang $750 \mathrm{~nm}$. Larutan standar asam galat menggunakan konsentrasi 3,125 ppm, 6,25 ppm, 12,5 ppm, 25 ppm, 50 ppm, dan 100 ppm. Prosedur pengukuran total fenolik pada larutan standar dibuat dengan mengganti sampel dengan larutan asam galat. Total senyawa fenolik dinyatakan dalam Gallic Acid Equivalent (GAE).

\subsection{Pengamatan penurunan mutu produk bawang tunggal hitam}

Bawang tunggal hitam dalam bentuk utuh dan ekstrak dikemas dalam kemasan PET sedangkan mikroenkapsulat menggunakan metalized plastic. Penyimpanan dilakukan dalam inkubator dengan suhu $30^{\circ} \mathrm{C}, 35^{\circ} \mathrm{C}$, dan $40^{\circ} \mathrm{C}$ selama 49 hari. Pengamatan dilakukan pada hari ke-0, 7, 14, 28, 35, 42, dan 49 .

\subsection{Penentuan umur simpan}

Penentuan umur simpan diawali dengan memplotkan data hasil pengamatan pada grafik hubungan antar waktu penyimpanan (sumbu $x$ ) dengan nilai mutu (sumbu $y$ ). Langkah berikutnya adalah menentukan persamaan kinetika perubahan parameter dengan mengacu pada persamaan laju reaksi ordo 0 dan ordo 1 .

$$
\begin{aligned}
& \text { Ordo } 0: r=k[A]^{0} \\
& \text { Ordo 1: } r=k[A]^{1}
\end{aligned}
$$

$$
\begin{aligned}
& \text { Keterangan: } \\
& \mathrm{r} \quad=\text { laju reaksi } \\
& \mathrm{k} \quad=\text { tetapan laju reaksi } \\
& {[\mathrm{A}]=\text { konsentrasi zat. }}
\end{aligned}
$$

Pengaruh suhu terhadap laju reaksi dapat dideskripsikan menggunakan hubungan Arrhenius. Nilai $\mathrm{k}$ yang diperoleh pada setiap suhu penyimpanan selanjutnya diplotkan pada kurva Arrhenius dengan sumbu $x(1 / \mathrm{T})$ dan sumbu $y$ (ln k). Slope yang diperoleh dari persamaan Arrhenius merupakan nilai $\mathrm{Ea} / \mathrm{R}$, sedangkan $y=0$ merupakan nilai $\ln \mathrm{k}_{0}$. Nilai $\mathrm{k}$ pada kisaran suhu yang lebih luas dihitung dari persamaan Arrhenius sebagai berikut:

$$
k=k_{0} e^{-E a / R T}
$$

Keterangan :

$\mathrm{k} \quad=$ laju reaksi

$\mathrm{k}_{0} \quad=$ konstanta absolut

$\mathrm{Ea}=$ energi aktivasi $(\mathrm{J} / \mathrm{mol})$

$\mathrm{T}=\operatorname{suhu}(\mathrm{K})$

$\mathrm{R}=$ konstanta gas $(8,314 \mathrm{~J} / \mathrm{mol} . \mathrm{K})$. 
Persamaan tersebut diubah menjadi:

$$
\ln k=\ln k_{0}-\frac{E_{a}}{R} \frac{1}{T}
$$

Setelah memperoleh nilai $\mathrm{k}$ pada suhu yang diinginkan, umur simpan dihitung dengan kinetika reaksi berdasarkan ordo reaksi terpilih. Umur simpan dapat dihitung dengan persamaan:

$$
\begin{array}{r}
\text { Ordo 0:t } t=\frac{A_{0}-A}{k} \\
\text { Ordo } 1: t=\frac{\ln A_{0}-\ln A}{k}
\end{array}
$$

Keterangan :

$\mathrm{t} \quad=$ umur simpan (hari)

$\mathrm{A}_{0}=$ nilai mutu awal

$\mathrm{A}=$ nilai kritis mutu

$\mathrm{k} \quad=$ laju kinetika perubahan mutu

Bawang tunggal hitam merupakan produk yang berfungsi sebagai bahan pangan fungsional. Pendekatan umur simpan yang dipilih adalah produk suplemen. Menurut (Arpah, 2007) umur simpan produk suplemen dicapai saat usable quality $85 \%$. Artinya, saat kandungan senyawa bioaktifnya menyisakan $85 \%$ umur produk berakhir.

\section{Hasil dan pembahasan \\ 3.1. Karakteristik produk}

Bawang tunggal hitam merupakan produk olahan dari bawang putih yang diinkubasi atau aging pada suhu dan kelembaban tinggi. Secara umum, tujuan dari adanya proses pemanasan adalah untuk meningkatkan sifat sensoris, palatabilitas, dan memperbaiki warna, rasa, dan tekstur (Capuano dan Fogliano, 2011). Proses inkubasi menyebabkan bawang putih mengalami perubahan warna menjadi hitam, rasa menjadi lebih manis, dan berkurangnya bau menyengat akibat adanya reaksi Maillard (Handayani et al., 2018). Rasa manis disebabkan karena meningkatnya kandungan gula (glukosa, fruktosa, sukrosa, dan maltosa) (Choi et al., 2014). Kenampakan fisik sediaan bawang tunggal hitam dapat dilihat pada Gambar 1.

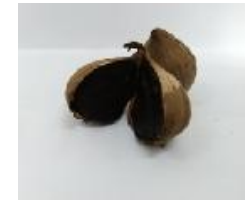

A

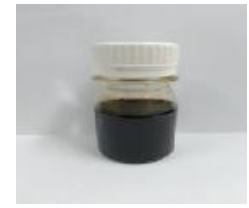

B

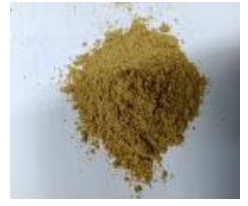

$\mathrm{C}$
Gambar 1. Sediaan bawang tunggal hitam (A) utuh, (B) ekstrak dan (C) mikroenkapsulat

Bagian dalam bawang tunggal hitam utuh memiliki tekstur kenyal seperti jeli. Ekstrak bawang tunggal hitam memiliki warna hitam pekat, bau khas bawang tunggal hitam, dan kental. Warna hitam disebabkan adanya produk hasil reaksi Mailard. Mikroenkapsulat berbentuk bubuk halus, bau khas bawang tunggal hitam, dan berwarna cokelat. Penambahan bahan penyalut menyebabkan warna hitam dari ekstrak menjadi cokelat pada sediaan mikroenkapsulat.
Kapasitas antioksidan dan total fenolik menjadi parameter yang dipilih dalam pendugaan umur simpan. Parameter tersebut tersebut tersaji pada Tabel 1.

Tabel 1.

Karakterisasi awal sediaan bawang tunggal hitam

\begin{tabular}{lll}
\hline $\begin{array}{l}\text { Sediaan bawang } \\
\text { tunggal hitam }\end{array}$ & Parameter & \\
\cline { 2 - 3 } & AEAC & Total fenolik \\
\hline Utuh & $0,1048 \mathrm{mg} \mathrm{g}^{-1}$ & $0,2037 \mathrm{mg} \mathrm{GAE} \mathrm{g}^{-1}$ \\
Ekstrak & $0,0625 \mathrm{mg} \mathrm{ml}^{-1}$ & $0,4514 \mathrm{mg} \mathrm{GAE} \mathrm{ml}^{-1}$ \\
Mikroenkapsulat & $0,1111 \mathrm{mg} \mathrm{g}^{-1}$ & $0,2141 \mathrm{mg} \mathrm{GAE} \mathrm{g}^{-1}$
\end{tabular}

Keterangan AEAC: Ascorbic acid Equivalent Antioxidant Capacity; GEA: Gallic Acid Equivalent

Bawang tunggal hitam mengandung senyawa bioaktif yang memiliki aktivitas antioksidan seperti s-allylcysteine (SAC), tetrahydro- $\beta$-carboline, dan senyawa polifenol termasuk didalamnya senyawa-senyawa flavonoid (Choi et al., 2014). Sediaan mikroenkapsulat memiliki kapasitas antioksidan yang lebih tinggi dibandingkan sediaan lainnya. Proses enkapsulasi dapat melindungi senyawa bioaktif dalam eksrak bawang tunggal hitam selama penyimpanan, sehingga kapasitas antioksidannya tinggi. Sediaan ekstrak memiliki kapasitas antioksidan terendah, namun kandungan fenolik tertinggi. Proses ekstraksi dipengaruhi oleh jenis pelarut yang digunakan. Perbedaan karakteristik kimia dan polaritas menyebabkan larut dan tidak larutnya senyawa bioaktif dalam pelarut (Wungkana et al., 2013; Ngan et al., 2017). Aktivitas antioksidan dari suatu bahan tidak hanya terbatas pada senyawa fenol saja (Javanmardi et al., 2003). Kandungan total fenolik yang tinggi pada sediaan ekstrak tidak memberikan kapasitas antioksidan yang tertinggi. Proses ekstraksi menghasilkan senyawa yang bersifat antioksidan yang berbeda-beda dalam polaritas dan karakteristik kimia (Ngan et al., 2017).

\subsection{Kinetika perubahan mutu selama penyimpanan 3.2.1. Kapasitas antioksidan}

Bawang tunggal hitam mempunyai kapasitas antioksidan yang tinggi (Bae et al., 2014; Choi et al., 2014; Jeong et al., 2016; Kimura et al., 2017; Lee et al., 2009). Kapasitas antioksidan pada bawang hitam berhubungan dengan kandungan total fenolik, flavonoid dan senyawa intermediet dari reaksi Mailard (Choi et al., 2014; Lu et al., 2017). Pengamatan kapasitas antioksidan selama penyimpanan tersaji pada Gambar 2. Selama penyimpanan kapasitas antioksidan sediaan bawang tunggal hitam mengalami penurunan. Kerusakan senyawa antioksidan dapat disebabkan oleh oksidasi pemutusan ikatan kovalen maupun peningkatan laju reaksi oksidasi oleh panas (Patras et al., 2009). Senyawa yang teroksidasi akan menjadi rusak dan kapasitas antioksidannya menurun. Penyimpanan pada suhu $40^{\circ} \mathrm{C}$ memiliki penurunan yang lebih besar dibandingkan suhu lainnya. Suhu merupakan faktor yang dapat mepercepat reaksi kimia dan biologi (Haouet et al., 2018).

Koefisien determinasi $\left(\mathrm{R}^{2}\right)$ dan laju kinetika reaksi (k) kapasitas antioksidan yang diperoleh dari memplotkan data pengamatan (Tabel 2.). Semua 
persamaan sediaan bawang tunggal hitam memiliki nilai $\mathrm{R}^{2}>0,7$. Nilai tersebut sudah cukup menunjukan adanya korelasi yang erat antar data selama pengamatan. Pada persamaan ordo 0 dan 1 dari setiap sediaan, nilai $\mathrm{R}^{2}$ hanya berbeda sedikit, sehingga pendekatan persamaan Arrhenius untuk kapasitas antioksidan menggunakan keduanya. Laju kinetika rekasi (k) menunjukan laju penurunan mutu yang terjadi ketika produk disimpan pada kondisi yang digunakan. Berdasarkan Tabel 2., nilai $\mathrm{k}$ untuk setiap sediaan bawang tunggal hitam meningkat seiring dengan peningkatan suhu penyimpanan. Penurunan kapasitas antioksidan yang terjadi pada mikroenkapsulat lebih cepat dibandingkan sediaan lainnya. Hal ini dapat terjadi karena kurang baiknya proses penyalutan (coating) pada proses mikroenkapsulasi. Penggunaan satu penyalut akan mempermudah proses mikroenkapsulasi, namun memiliki kelemahan pada stabilitas mikroenkapsulat saat penyimpanan. Produk mikroenkapsulat akan mudah mengalami kenaikan kadar air (menjadi kempal) dan senyawa bioaktif mudah teroksidasi. Komposisi material penyalut akan menentukan karakteristik fisik mikroenkapsulat (Purnamayati et al., 2016).

Senyawa antioksidan pada sediaan bawang hitam utuh lebih banyak jenisnya dibandingkan pada sediaan ekstrak dan mikroenkapsulat. Perbedaan sifat polaritas dan sifat kimia lainnya pada senyawa antioksidan akan memberikan efek sinergi saat penyimpanan. Sinergi ini dapat memberikan nilai kapasistas antioksidan yang tinggi pada saat dianalisis, namun juga dapat menurunkan nilai karena adanya penghambatan antar senyawa antioksidan. Penyimpanan pada beberapa suhu menunjukan adanya perbedaan respon pada kapasitas antioksidan. Pada awal penyimpanan suhu $35^{\circ} \mathrm{C}$ terjadi peningkatan kapasitas antioksidan. Hal ini dapat disebabkan oleh berubahnya senyawa asam-asam amino dan gula menjadi senyawa bersifat antioksidan, seperti SAC dan hydroxy methyl furfural (HMF).

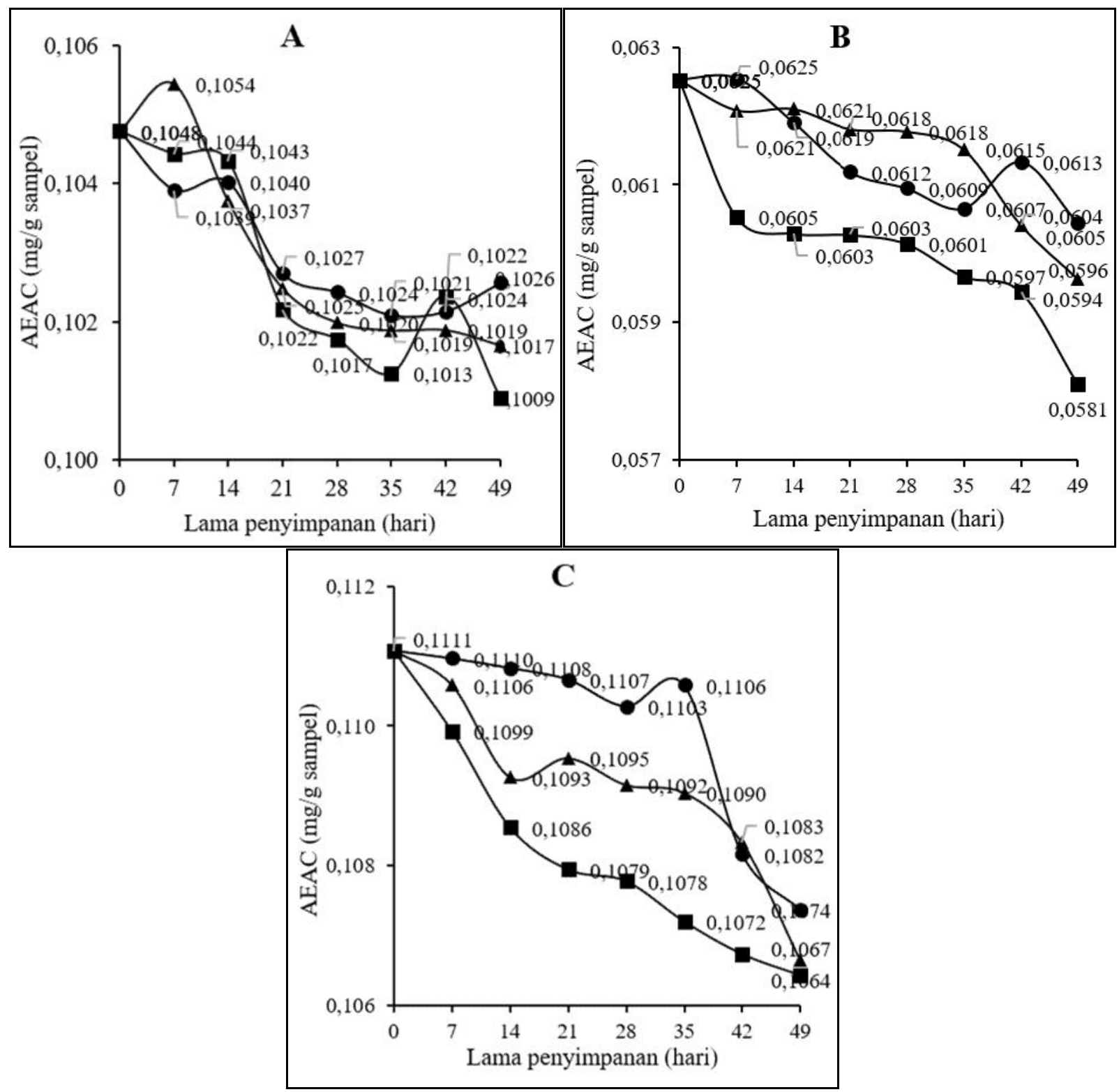

Gambar 2. Grafik penurunan kapasitas antioksidan sediaan bawang tunggal hitam (A) utuh, (B) ekstrak dan (C) mikroenkapsulat pada suhu $(\bullet) 30^{\circ} \mathrm{C},(\bullet) 35^{\circ} \mathrm{C}$ dan $(\bullet) 40^{\circ} \mathrm{C}$ 
Tabel 2.

Nilai koefisien determinasi dan laju kinetika reaksi kapasitas antioksidan

\begin{tabular}{|c|c|c|c|c|c|c|c|c|}
\hline \multirow{3}{*}{$\begin{array}{l}\text { Parameter } \\
\text { mutu }\end{array}$} & \multirow{3}{*}{$\begin{array}{l}\text { Orde } \\
\text { reaksi }\end{array}$} & \multirow{3}{*}{$\begin{array}{l}\text { Suhu } \\
\left({ }^{\circ} \mathrm{C}\right)\end{array}$} & \multicolumn{6}{|c|}{ Sediaan bawang tunggal hitam } \\
\hline & & & \multicolumn{2}{|l|}{ Utuh } & \multicolumn{2}{|c|}{ Ekstrak } & \multicolumn{2}{|c|}{ Mikroenkapsulat } \\
\hline & & & $\mathrm{R}^{2}$ & $\mathrm{k}$ & $\mathrm{R}^{2}$ & $\mathrm{k}$ & $\mathrm{R}^{2}$ & $\mathrm{k}$ \\
\hline \multirow{6}{*}{$\begin{array}{l}\text { Kapasitas } \\
\text { antioksidan }\end{array}$} & \multirow{3}{*}{ Ordo 0} & 30 & 0,81 & 0,0000513 & 0,79 & 0,000042 & 0,93 & 0,0000696 \\
\hline & & 35 & 0,80 & 0,0000776 & 0,83 & 0,000052 & 0,72 & 0,0000740 \\
\hline & & 40 & 0,77 & 0,0000800 & 0,82 & 0,000065 & 0,88 & 0,0000905 \\
\hline & \multirow{3}{*}{ Ordo 1} & 30 & 0,82 & 0,0004970 & 0,79 & 0,000676 & 0,93 & 0,0006390 \\
\hline & & 35 & 0,80 & 0,0007510 & 0,83 & 0,000844 & 0,72 & 0,0006740 \\
\hline & & 40 & 0,77 & 0,0007770 & 0,82 & 0,001080 & 0,87 & 0,0008240 \\
\hline
\end{tabular}

\subsubsection{Total fenolik}

Proses aging pada bawang tunggal hitam akan menyebabkan peningkatan senyawa polifenol karena meningkatnya fraksi bebas asam fenolik, fraksi ester dan glikosida menurun sehingga bentuk fenol bebas meningkat (Handayani et al., 2018). Kandungan fenolik meningkat selama inkubasi bawang putih dan terbesar diperoleh pada inkubasi 21 hari (Choi et al., 2014). Menurut Kim et al. (2013) dan $\mathrm{Lu}$ et al. (2017) total fenolik meningkat 10 kali lipat dibandingkan bawang putih.

Gambar 3. menunjukan bahwa total fenolik sediaan bawang tunggal hitam mengalami penurunan selama penyimpanan. Penurunan total fenolik semakin cepat dengan meningkatnya suhu penyimpanan. Degradasi kimia terjadi karena meningkatnya suhu (Asiah et al., 2018). Peristiwa ini sama seperti pada kapasitas antioksidan. Senyawa fenolik dapat berfungsi sebagai antioksidan (Kähkönen et al., 1999; Rehman et al., 2011; Liu et al., 2019), karena senyawa tersebut memiliki sifat redox yang mereduksi radikal bebas, menetralisir prooksidan lainnya (Kappel et al., 2008), memindahkan elektron yang tidak berpasangan, dan mengkelat transisi logam (Afanas'ev et al., 1989). Pengggunaan air sebagai pelarut pada proses ekstraksi menyebabkan terakumulasinya senyawa fenolik dengan kepolaran yang sama dengan air. Ekstrak yang terambil lebih banyak mengandung senyawa fenolik dalam bentuk eter dan ester fenol, dibandingkan dengan senyawa fenolik tunggal dan senyawa glikosidanya.

Berdasarkan data pada Tabel 3, semua sediaan memiliki nilai $\mathrm{R}^{2}>0,7$ dan nilai $\mathrm{k}$ meningkat seiring dengan peningkatan suhu penyimpanan. Sediaan ekstrak memiliki nilai $\mathrm{k}$ yang paling tinggi. Penurunan ini disebabkan tidak ada lapisan yang dapat menahan interaksi antara senyawa fenolik dengan faktor-faktor penyebab kerusakan seperti suhu, oksigen, dan uap air. Pada bawang tunggal hitam utuh terdapat lapisan kulit luar dan senyawa-senyawa lain seperti karbohidrat, lemak dan protein yang dapat memperlambat interaksi senyawa fenolik dengan faktor-faktor yang dapat menyebabkan kerusakan. Cahaya dan oksigen dapat menyebabkan oksidasi dari fenol. Gugus aromatic pada fenol memiliki sifat mudah mengalami autooksidasi (Vermerris dan Nicholson, 2008).

Penurunan kapasitas antioksidan selama penyimpanan seiring dengan penurunan total fenolik. Sifat senyawa fenolik berkaitan erat dengan fungsinya sebagai antioksidan. Selama penyimpanan, senyawa fenolik yang terukur sebagai asam galat mengalami perubahan struktur atau terdekomposisi menjadi senyawa baru yang tidak dapat terukur. Sehingga total fenolik menurun. Migrasi air dan oksigen dari udara ke sediaan bawang hitam menyebabkan oksidasi dan reaksi enzimatis senyawa fenolik menjadi senyawa quinon yang menyebabkan warna menjadi lebih gelap.

Tabel 3.

Nilai koefisien determinasi dan laju kinetika reaksi total fenolik

\begin{tabular}{|c|c|c|c|c|c|c|c|c|}
\hline \multirow{3}{*}{$\begin{array}{l}\text { Parameter } \\
\text { mutu }\end{array}$} & \multirow{3}{*}{$\begin{array}{l}\text { Orde } \\
\text { reaksi }\end{array}$} & \multirow{3}{*}{$\begin{array}{l}\text { Suhu } \\
\left({ }^{\circ} \mathrm{C}\right)\end{array}$} & \multicolumn{6}{|c|}{ Sediaan bawang tunggal hitam } \\
\hline & & & \multicolumn{2}{|l|}{ Utuh } & \multicolumn{2}{|c|}{ Ekstrak } & \multicolumn{2}{|c|}{ Mikroenkapsulat } \\
\hline & & & $\mathrm{R}^{2}$ & $\mathrm{k}$ & $\mathrm{R}^{2}$ & $\mathrm{k}$ & $R^{2}$ & $\mathrm{k}$ \\
\hline \multirow{6}{*}{$\begin{array}{l}\text { Total } \\
\text { fenolik }\end{array}$} & \multirow{3}{*}{ Ordo 0} & 30 & 0,88 & 0,001800 & 0,74 & 0,000404 & 0,87 & 0,001850 \\
\hline & & 35 & 0,90 & 0,000202 & 0,95 & 0,000874 & 0,84 & 0,000327 \\
\hline & & 40 & 0,74 & 0,000237 & 0,95 & 0,001090 & 0,87 & 0,000423 \\
\hline & \multirow{3}{*}{ Ordo 1} & 30 & 0,88 & 0,000909 & 0,74 & 0,000920 & 0,86 & 0,000882 \\
\hline & & 35 & 0,90 & 0,001010 & 0,96 & 0,002040 & 0,85 & 0,001620 \\
\hline & & 40 & 0,73 & 0,001200 & 0,95 & 0,002560 & 0,87 & 0,002120 \\
\hline
\end{tabular}




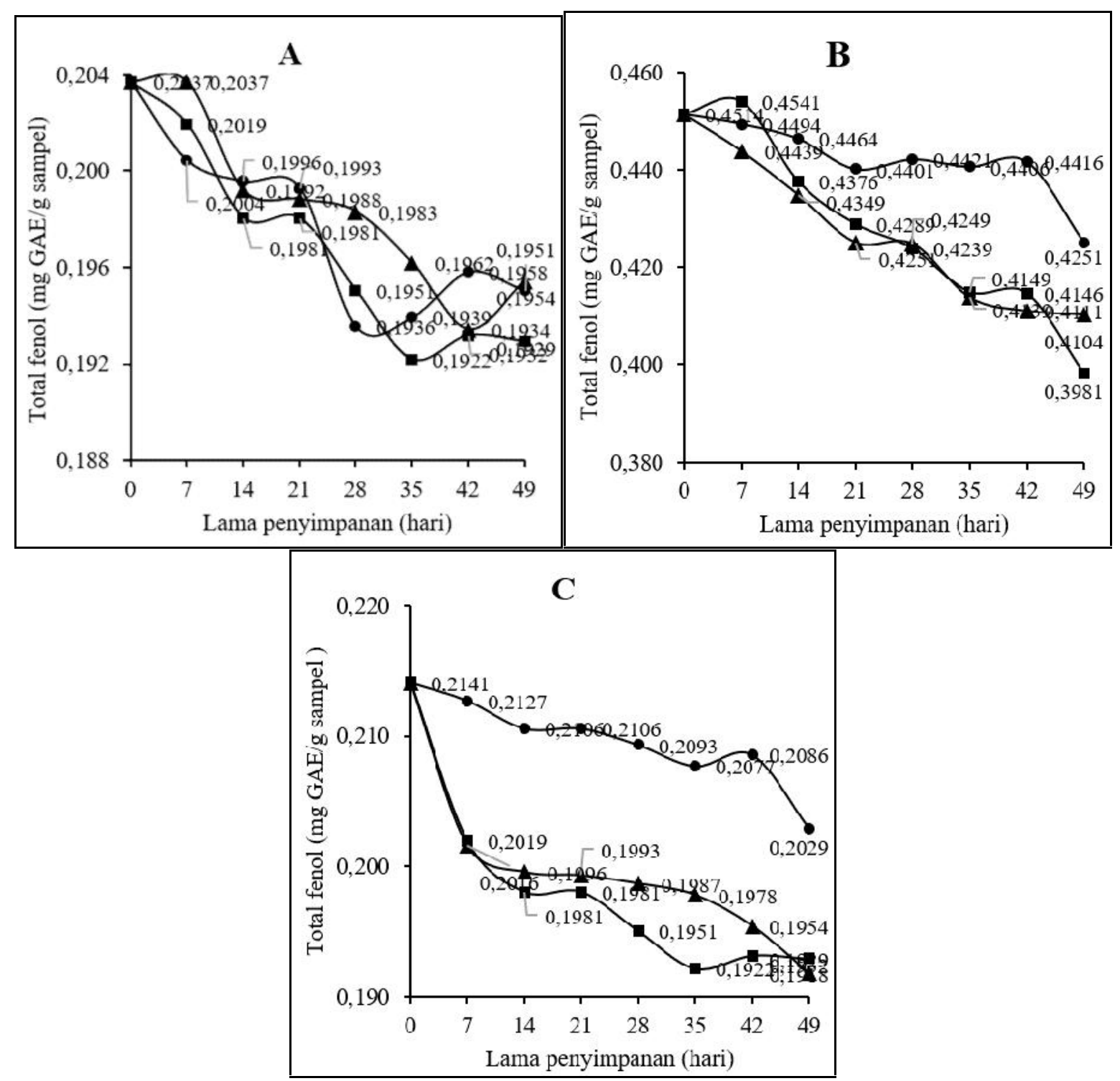

Gambar 3. Grafik penurunan total fenolik sediaan bawang tunggal hitam (A) utuh, (B) ekstrak dan (C mikroenkapsulat pada suhu (•) $30^{\circ} \mathrm{C},(\bullet) 35^{\circ} \mathrm{C}$ dan $(\bullet) 40^{\circ} \mathrm{C}$

\subsection{Pendugaan umur simpan}

Penurunan kualitas suatu produk dapat disebabkan karena reaksi kimia (oksidasi, denaturasi, hidrolisis), perubahan biologis, atau kolaborasi keduanya seperti reaksi enzimatis oleh mikrobia. Faktor intrinsik $(\mathrm{pH}$, kandungan nutrisi, aktivitas air, anti mikrobia) dan ekstrinsik (kemasan, kondisi penyimpanan) berperan dalam menentukan umur simpan.

Nilai kritis mutu yang digunakan penelitian ini adalah usable quality $85 \%$ (Tabel 4.). Standar ini dipilih dengan mempertimbangkan kondisi produk saat dikonsumsi masih memiliki kandungan senyawa biokatif yang cukup tinggi. Pertimbangan lainnya adalah produk ekstrak dan mikroenkapsulat merupakan produk setengah jadi (produk antara) yang akan mengalami proses pengolahan lebih lanjut.

Tabel 5 menyajikan persamaan Arrhenius, energi aktivasi, dan nilai koefisien determinasi. Energi aktivasi merupakan besarnya energi minimun yang dibutuhkan agar reaksi dapat berjalan. Besarnya pengaruh suhu terhadap reaksi dapat digambarkan dengan besarnya energi aktivasi. Semakin rendah energi aktivasi, reaksi akan semakin cepat dan semakin cepat pula kerusakan yang terjadi. Nilai energi aktivasi digolongkan menjadi tiga yaitu kecil (2-15 $\mathrm{kkal} / \mathrm{mol})$, sedang (15-30 $\mathrm{kkal} / \mathrm{mol}$ ), dan tinggi (50-100 kkal/mol) (Arpah, 2007). Dari acuan tersebut, energi aktivasi penurunan antioksidan dan total fenolik sediaan utuh digolongkan kedalam energi aktivasi yang rendah. Sedangkan sediaan ekstrak dan mikroenkapsulat memiliki energi aktivasi penurunan antioksidan yang kecil dan penurunan total fenolik yang sedang. Pada sediaan ekstrak dan mikroenkapsulat, untuk memulai reaksi penurunan total fenolik memerlukan energi yang lebih besar dibandingkan penurunan antioksidan.

Berdasarkan data pada Tabel 6, parameter total fenolik memiliki pendugaan umur simpan yang lebih pendek dibandingkan antioksidan. Senyawa fenol mudah rusak oleh suhu, uap air, oksigen dan cahaya. Walaupun energi aktivasi antioksidan pada sediaan ekstrak dan mikroenkapsulat lebih rendah namun karena laju kinetika reaksi juga lebih rendah, sehingga pendugaan umur simpan dengan parameter antioksidan lebih lama. 
Total fenolik menjadi parameter dalam pendugaan umur simpan sediaan bawang tunggal hitam

Tabel 4. Nilai kritis mutu

\begin{tabular}{lll}
\hline $\begin{array}{l}\text { Sediaan bawang } \\
\text { tunggal hitam }\end{array}$ & Parameter & Nilai kritis mutu \\
\hline Utuh & $\begin{array}{l}\text { Kapasitas } \\
\text { antioksidan } \\
\text { Total fenolik }\end{array}$ & $0,0891 \mathrm{AEAC} \mathrm{mg} \mathrm{g}^{-1}$ \\
\hline Ekstrak & $\begin{array}{l}\text { Kapasitas } \\
\text { antioksidan }\end{array}$ & $0,0531 \mathrm{mg} \mathrm{GAE} \mathrm{g}^{-1}$ \\
\hline Total fenolik & $0,3837 \mathrm{mg} \mathrm{GAE} \mathrm{mg} \mathrm{m}^{-1}$ \\
\hline \multirow{2}{*}{ Mikroenkapsulat } & $\begin{array}{l}\text { Kapasitas } \\
\text { antioksidan } \\
\text { Total fenolik }\end{array}$ & $0,0944 \mathrm{AEAC} \mathrm{mg} \mathrm{g}^{-1}$ \\
& $0,1820 \mathrm{mg} \mathrm{GAE} \mathrm{g}^{-1}$ \\
\hline
\end{tabular}

Perbedaan nilai $\mathrm{R}^{2}$ pada ordo 0 dan 1 yang kecil memberikan pendugaan umur simpan yang tidak berbeda jauh. Pada parameter kapasitas antioksidan dan total fenolik, hampir semua pendugaan umur simpan lebih pendek pada ordo 0, kecuali total fenol pada sediaan utuh. Namun, karena perbedaan umur simpan sediaan utuh dengan parameter total fenolik kecil, maka semua sediaan ditetapkan pendugaan umur simpannya menggunakan orde reaksi 0 . Penurunan kualitas kapasitas antioksidan dan total fenolik pada sediaan bawang tunggal hitam memiliki persamaan yang linear dengan waktu penyimpanan. Sehingga pada suhu $25^{\circ} \mathrm{C}$, sediaan bawang tunggal hitam utuh memiliki umur simpan 199 hari, ekstrak 259 hari, dan mikroenkapsulat 255 hari.

Penggunaan kemasan PET dan metalized plastic bertujuan mengurangi laju kerusakan (penurunan mutu) sediaan selama penyimpanan. Pendugaan umur simpan lebih dari 6 bulan (>180 hari) menunjukan kemasan yang dipilih sudah cukup mengurangi laju kerusakan. Hasil berbeda akan terjadi jika digunakan kemasan dan kondisi penyimpanan yang berbeda.

Tabel 5. Persamaan Arrhenius, energi aktivasi dan koefisien determinasi penentuan umur simpan sediaan bawang tunggal hitam

\begin{tabular}{|c|c|c|c|c|c|}
\hline Sediaan bawang tunggal hitam & Parameter & Ordo & Persamaan arrhenius & $\mathrm{Ea}(\mathrm{kkal} / \mathrm{mol})$ & $\mathrm{R}^{2}$ \\
\hline \multirow{4}{*}{ Utuh } & \multirow{2}{*}{ Kapasitas antioksidan } & 0 & $\ln \mathrm{k}=-4233,34(1 / \mathrm{T})+4,1553$ & 8,38 & 0,81 \\
\hline & & 1 & $\ln \mathrm{k}=-4256,95(1 / \mathrm{T})+6,5033$ & 8,43 & 0,81 \\
\hline & \multirow{2}{*}{ Total fenolik } & 0 & $\ln \mathrm{k}=-2646,76(1 / \mathrm{T})+0,1055$ & 5,24 & 0,99 \\
\hline & & 1 & $\ln \mathrm{k}=-2626,32(1 / \mathrm{T})+1,7195$ & 5,24 & 0,98 \\
\hline \multirow{4}{*}{ Ekstrak } & \multirow{2}{*}{ Kapasitas antioksidan } & 0 & $\ln \mathrm{k}=-4140,93(1 / \mathrm{T})+3,5859$ & 8,20 & 0,99 \\
\hline & & 1 & $\ln \mathrm{k}=-4441,77(1 / \mathrm{T})+7,3547$ & 8,79 & 0,99 \\
\hline & \multirow{2}{*}{ Total fenolik } & 0 & $\ln \mathrm{k}=-9474,92(1 / \mathrm{T})+23,5434$ & 18,76 & 0,91 \\
\hline & & 1 & $\ln \mathrm{k}=-9737,71(1 / \mathrm{T})+25,2369$ & 19,28 & 0,91 \\
\hline \multirow{4}{*}{ Mikroenkapsulat } & \multirow{2}{*}{ Kapasitas antioksidan } & 0 & $\ln \mathrm{k}=-2482,93(1 / \mathrm{T})-1,4019$ & 4,92 & 0,91 \\
\hline & & 1 & $\ln \mathrm{k}=-2403,65(1 / \mathrm{T})+0,5523$ & 4,76 & 0,89 \\
\hline & \multirow{2}{*}{ Total fenolik } & 0 & $\ln \mathrm{k}=-7858,67(1 / \mathrm{T})+17,3900$ & 15,56 & 0,96 \\
\hline & & 1 & $\ln \mathrm{k}=-8333,79(1 / \mathrm{T})+20,5240$ & 16,50 & 0,96 \\
\hline
\end{tabular}

Tabel 6

Prediksi umur simpan sediaan bawang tunggal hitam pada suhu $25^{\circ} \mathrm{C}$

\begin{tabular}{lllllll}
\hline $\begin{array}{l}\text { Sediaan bawang } \\
\text { tunggal hitam }\end{array}$ & Parameter & Suhu & Ordo & & Ordo 1 & \\
\cline { 5 - 7 } Utuh & $\begin{array}{l}\text { Kapasitas } \\
\text { antioksidan } \\
\text { Total fenolik }\end{array}$ & $25^{\circ} \mathrm{C}$ & 0,0000430 & 365 & 0,000170 & 389 \\
\hline \multirow{2}{*}{ Ekstrak } & $\begin{array}{l}\text { Kapasitas } \\
\text { antioksidan }\end{array}$ & $25^{\circ} \mathrm{C}$ & 0,0000154 & 199 & 0,000830 & 196 \\
\hline \multirow{2}{*}{ Mikroenkapsulat } & $\begin{array}{l}\text { Total fenolik } \\
\text { Kapasitas } \\
\text { antioksidan } \\
\text { Total fenolik }\end{array}$ & $25^{\circ} \mathrm{C}$ & 0,0000330 & 285 & 0,000526 & 310 \\
& $25^{\circ} \mathrm{C}$ & 0,0002610 & 259 & 0,000587 & 277 \\
\hline
\end{tabular}

\section{Kesimpulan}

Parameter mutu kapasitas antioksidan dan total senyawa fenolik bawang tunggal hitam utuh, ekstrak, dan mikroenkapsulat mengalami penurunan selama penyimpanan. Penurunan kedua parameter tersebut semakin cepat dengan meningkatnya suhu penyimpanan. Penurunan mutu mengikuti persamaan linear (ordo 0). Total senyawa fenolik digunakan sebagai parameter kritis karena paling sensitif terhadap suhu. Sediaan bawang tunggal hitam utuh memiliki umur simpan 199 hari, ekstrak bawang tunggal hitam 259 hari, dan mikroenkapsulat 255 hari pada suhu penyimpanan $25^{\circ} \mathrm{C}$.

\section{Ucapan terima kasih}

Penelitian ini memperoleh dana dari Program Insentif Riset Sistem Inovasi Nasional (INSINAS) 2019 Kementrian Riset Teknologi dan Perguruan Tinggi Republik Indonesia. 


\section{Daftar pustaka}

Afanas'ev, I.B., Dcrozhko, A.I., Brodskii, A. V., Kostyuk, V.A., Potapovitch, A.I., 1989. Chelating and free radical scavenging mechanisms of inhibitory action of rutin and quercetin in lipid peroxidation. Biochem. Pharmacol. 38, 1763-1769. https://doi.org/10.1016/0006-2952(89)90410-3

Agoes, G., 2007. Teknologi bahan alam. ITB Press, Bandung.

Arif, A. Bin, 2016. Metode accelarated shelf life test (ASLT) dengan pendekatan arrhenius dalam pendugaan umur simpan sari buah nanas pepaya dan cempedak. Inform. Pertanian, 25, 189-198. https://doi.org/10.3989/sefarad.011.001

Arpah, M., 2007. Penetapan kadaluwarsa pangan. Departemen Ilmu dan Teknologi Pangan Institut Pertanian Bogor, Bogor.

Asiah, N., Cempaka, L., David, W., 2018. Panduan praktis pendugaan umur simpan Produk pangan. Universitas Bakrie, Jakarta.

Bae, S.E., Cho, S.Y., Won, Y.D., Lee, S.H., Park, H.J., 2014. Changes in S-allyl cysteine contents and physicochemical properties of black garlic during heat treatment. LWT - Food Sci. Technol. 55, 397402. https://doi.org/10.1016/j.lwt.2013.05.006

Bae, S.E., Cho, S.Y., Won, Y.D., Lee, S.H., Park, H.J., 2012. A comparative study of the different analytical methods for analysis of S-allyl cysteine in black garlic by HPLC. LWT - Food Sci. Technol. 46, 532535. https://doi.org/10.1016/j.lwt.2011.11.013

Budijanto, S., Sitanggang, A.B., Silalahi, B.E., Murdiati, W., 2010. Penentuan umur simpan seasoning menggunakan metode accelerated shelf-life testing (ASLT) dengan pendekatan kadar air kritis. J. Teknol. Pertan. 11, 71-77.

Capuano, E., Fogliano, V., 2011. Acrylamide and 5hydroxymethylfurfural (HMF): A review on metabolism, toxicity, occurrence in food and mitigation strategies. LWT - Food Sci. Technol. 44, 793-810. https://doi.org/10.1016/j.lwt.2010.11.002

Choi, I.S., Cha, H.S., Lee, Y.S., 2014. Physicochemical and antioxidant properties of black garlic. Molecules 19, 16811-16823. https://doi.org/10.3390/molecules 191016811

Chu, Q., Lee, D.T.W., Tsao, S.W., Wang, X., Wong, Y.C., 2007. S-allylcysteine, a water-soluble garlic derivative, suppresses the growth of a human androgen-independent prostate cancer xenograft, CWR22R, under in vivo conditions. BJU Int. 99, 925-932. https://doi.org/10.1111/j.1464-410X.2006. 06639.x

Diniyah, N., Subagio, A., Akhiriani, A., 2015. Pendugaan umur simpan "beras cerdas" berbasis mocaf, tepung jagung menggunakan metode accelerated shelf-life testing (ASLT) pendekatan Arrhenius. J. Agro-based Ind. 32, 1-8.

Gitalasa, F., Rostini, I., Pratama, R.I., 2018. Estimation of shelf life using accelerated shelf life test (ASLT) method Arrhenius model on sheet nile Tilapia Jerky. Glob. Sci. J. 6, 62-69.

Ha, A.W., Ying, T., Kim, W.K., 2015. The effects of black garlic (Allium satvium) extracts on lipid metabolism in rats fed a high fat diet. Nutr. Res. Pract. 9, 30-36. https://doi.org/10.4162/nrp.2015.9. 1.30

Handayani, S.N.U.R., Bawono, L.C., Pramesti, D., Pratiwi, H.N., 2018. Isolasi senyawa polifenol black garlic dan uji toksisitasnya terhadap larva udang (Artemia salina Leach). J. Ilmu Kefarmasian Indones. $16,145-149$.

Haouet, M.N., Tommasino, M., Mercuri, M.L., Benedetti, F., Di Bella, S., Framboas, M., Pelli, S., Altissimi, M.S., 2018. Experimental accelerated shelf life determination of a ready-to-eat processed food. Ital. J. Food Saf. 7, 189-192. https://doi.org/10.4081/ijfs.2018.6919

Hariyadi, P., 2004. Prinsip-prinsip pendugaan masa kadaluwarsa dengan metode accelerated shelf life test. Pusat Studi Pangan dan Gizi Bogor Institut Pertanian Bogor, Bogor.

Herawati, H., 2008. Penentuan umur simpan pada produk pangan. Litbang Pertan. 27, 124-130.

Iriani, E.S., Widayanti, S.M., Miskiyah, M., Juniawati, J., 2014. Pengaruh ekstrak bawang putih terenkapsulasi terhadap karakteristik kemasan antimikroba. J. Kim. dan Kemasan 36, 271. https://doi.org/10.24817/jkk.v36i2.1895

Javanmardi, J., Stushnoff, C., Locke, E., Vivanco, J.M., 2003. Antioxidant activity and total phenolic content of Iranian Ocimum accessions. Food Chem. 83, 547550. https://doi.org/10.1016/S0308-8146(03)00151-1

Jedermann, R., Nicometo, M., Uysal, I., Lang, W., 2014. Reducing food losses by intelligent food logistics. Philos. Trans. R. Soc. A Math. Phys. Eng. Sci. 372. https://doi.org/10.1098/rsta.2013.0302

Jeong, Y.Y., Ryu, J.H., Shin, J.H., Kang, M.J., Kang, J.R., Han, J., Kang, D., 2016. Comparison of antioxidant and anti-inflammatory effects between fresh and aged black garlic extracts. Molecules 21, 1-15. https://doi.org/10.3390/molecules21040430

Kähkönen, M.P., Hopia, A.I., Vuorela, H.J., Rauha, J.P., Pihlaja, K., Kujala, T.S., Heinonen, M., 1999. Antioxidant activity of plant extracts containing phenolic compounds. J. Agric. Food Chem. 47, 3954-3962. https://doi.org/10.1021/jf9901461

Kappel, V.D., Costa, G.M., Scola, G., Silva, F.A., Landell, M.F., Valente, P., Souza, D.G., Vanz, D.C., Reginatto, F.H., Moreira, J.C.F., 2008. Phenolic content and antioxidant and antimicrobial properties of fruits of Capsicum baccatum L. var. pendulum at different maturity stages. J. Med. Food 11, 267-274. https://doi.org/10.1089/jmf.2007.626

Kim, I., Kim, Jin-young, Hwang, Y., Hwang, K., Om, A., Kim, Jae-hyun, Cho, K., 2011. The beneficial effects of aged black garlic extract on obesity and hyperlipidemia in rats fed a high-fat diet. J. Med. Plants Res. 5, 3159-3168.

Kim, J.S., Kang, O.J., Gweon, O.C., 2013. Comparison of phenolic acids and flavonoids in black garlic at different thermal processing steps. J. Funct. Foods 5, 80-86. https://doi.org/10.1016/j.jff.2012.08.006

Kimura, S., Tung, Y.C., Pan, M.H., Su, N.W., Lai, Y.J., Cheng, K.C., 2017. Black garlic: A critical review of its production, bioactivity, and application. J. Food Drug Anal. 25, 62-70. https://doi.org/10.1016/j.jfda. 


\subsection{1 .003}

Kurniadi, M., Bintang, R., Kusumaningrum, A., Nursiwi, A., Nurhikmat, A., Susanto, A., Angwar, M., Triwiyono, Frediansyah, A., 2017. Shelf life prediction of canned fried-rice using accelerated shelf life testing (ASLT) arrhenius method, in: IOP Conference Series: Earth and Environmental Science. p. 012029. https://doi.org/10.1088/1755-1315/

Lee, Y.-M., Gweon, O.-C., Seo, Y.-J., Im, J., Kang, M.J., Kim, M.-J., Kim, J.-I., 2009. Antioxidant effect of garlic and aged black garlic in animal model of type 2 diabetes mellitus. Nutr. Res. Pract. 3, 156. https://doi.org/10.4162/nrp.2009.3.2.156

Liu, Q., Tang, G.-Y., Zhao, C.-N., Gan, R.-Y., Li, H.-B., 2019. Antioxidant activities,phenolic profiles, and organic acid contents of fruit vinegars. Antioxidants 8, 78. https://doi.org/10.3390/antiox8040078

Lu, X., Li, N., Qiao, X., Qiu, Z., Liu, P., 2017. Composition analysis and antioxidant properties of black garlic extract. J. Food Drug Anal. 25, 340-349. https://doi.org/10.1016/j.jfda.2016.05.011

Muanda, F., Kone, D., Dicko, A., Soulimani, R., Younos, C., 2011. Phytochemical composition and antioxidant capacity of three malian medicinal plant parts. Evidence-Based Complement. Altern. Med. 2011, 1-7. https://doi.org/10.1093/ecam/nep109

Muliadi, 2019. Pendugaan umur simpan buah alpukat (Persea americanamill) berdasarkan total padatan terlarut menggunakan model arrhenius dan Q10. Universitas Syah Kuala.

Mulyono, A., Afriyanti, Basuki, J., Sukaryani, S., 2018. Pendugaan umur simpan sirum buah tin "Kharomah" dengan metode accelerated shelf life testing (ASLT). J. Ilmu dan Teknol. Pangan 4, 277-282.

Ngan, N., Giang, M., Tu, N., 2017. Biological activities of black garlic fermented with lactobacillus plantarum PN05 and some kinds of black garlic presenting inside vietnam. Indian J. Pharm. Educ. Res. 51, 672-678. https://doi.org/10.5530/ijper. 51.4.99

Park, C., Park, S., Chung, Y.H., Kim, G.Y., Choi, Y.W., Kim, B.W., Choi, Y.H., 2014. Induction of apoptosis by a hexane extract of aged black garlic in the human leukemic U937 cells. Nutr. Res. Pract. 8, 132-137. https://doi.org/10.4162/nrp.2014.8.2.132

Parsetiorini, O.E., 2011. Pendugaan umur simpan seasoning dan microencapsulated ginger powder dengan metode accelerated shelf life testing di PT Indesso Aroma. Institut Pertanian Bogor.

Patras, A., Brunton, N., Da Pieve, S., Butler, F., Downey, G., 2009. Effect of thermal and high pressure processing on antioxidant activity and instrumental colour of tomato and carrot purées. Innov. Food Sci. Emerg. Technol. 10, 16-22. https://doi.org/10.1016/j.ifset.2008.09.008

Pranoto, Y., Marseno, D.W., Teknologi, J., Pertanian, H., Pertanian, F.T., Mada, U.G., No, J.F., 2012. Perkiraan umur simpan kacang rendah lemak dilapisi dengan carboximethyl celulose menggunakan metode accelerated shelf-life test (ASLT). Agritech 32, 301307.
Puri, R.Y.A., Wijana, S., Pranowo, D., 2018. Analisis kualitas sirup baby java pada stasiun proses dan pendugan umur simpan skala pilot plan. J. Teknol. Pertan. 19, 125-138.

Purnamayati, L., Dewi, E.N., Kurniasih, R.A., 2016. Karakteristik fisik mikrokapsul fikosianin spirulina pada konsentrasi bahan penyalut yang berbeda. J. Teknol. Has. Pertan. 9, 1-8. https://doi.org/ 10.20961/jthp.v9i2.12844

Rahmawati, F., 2017. Pendugaan umur simpan mikroenkapsulat ekstrak dan tepung kulit buah manggis dengan metode accelerated shelf-life testing (aslt) faradis rahmawati. Institut Pertanian Bogor.

Rahmi, S., Ahmad, U., Wulandari, D., 2016. Pendugaan umur simpan benih kedelai menggunakan metode accelerated shelf-life testing (ASLT). J. Keteknikan Pertan. 4, 75-80. https://doi.org/10.19028/jtep.04. $1.75-80$

Rehman, R., Akram, M., Akhtar, N., Jabeen, Q., Shah, S.M.A., 2011. Zingiber officinale Roscoe (pharmacological activity). J. Med. Plants Res. 5, 344-348.

Reis, A.S. dos, Diedrich, C., Moura, C. de, Pereira, D., Almeida, J. de F., Silva, L.D. da, Plata-Oviedo, M.S.V., Tavares, R.A.W., Carpes, S.T., 2017. Physico-chemical characteristics of microencapsulated propolis co-product extract and its effect on storage stability of burger meat during storage at $-15{ }^{\circ} \mathrm{C}$. LWT - Food Sci. Technol. 76, 306-313. https://doi.org/10.1016/j.lwt.2016.05.033

Setyadjit, Sukasih, E., Arif, A. Bin, 2017. Prediction of storage life of shallot powder by using acceleration method. Int. J. Agric. Syst. 5, 140-153. https://doi.org/10.20956/ijas.v5i2.1236

Solco, A.K.S., 2007. Accelerated shelf-life test of alkamides in Echinacea purpurea root aqueous ethanol Soxhlet extracts. Iowa state University.

Steele, R. (Ed.), 2000. Temperature and food stability: analysis and control, in: Understanding and measuring the shelf-life of food. CRC Press LLC, pp. 42-65.

Susanti, M., 2008. Mikroenkapsulasi oleoresin daun sirih (Piper betle L.) untuk produksi bandeng (Chanoschanos forsk) tinggi lisin pada proses pengasapan cair. J. Litbang Provinsi Jawa Teng. 6, 38-51.

Vermerris, W., Nicholson, R., 2008. Phenolic compound biochemistry, 1st ed. Springer Science + Business Media B.V, USA.

Wang, W., Sun, Y., 2017. In vitro and in vivo antioxidant activities of polyphenol extracted from black garlic. Food Sci. Technol. 37, 681-685. https://doi.org/10.1590/1678-457x.30816

Wungkana, I., Suryanto, E., Momuat, L., 2013. Aktivitas antioksidan dan tabir surya fraksi fenolik dari limbah tongkol jagung (Zea mays L.). Pharmacon 2, 149155 .

Zhang, X., Li, N., Lu, X., Liu, P., Qiao, X., 2016. Effects of temperature on the quality of black garlic. J. Sci. Food Agric. 96, 2366-2372. https://doi.org/ $10.1002 /$ jsfa. 7351 